Egyptian Journal of Aquatic Biology \& Fisheries

Zoology Department, Faculty of Science,

Ain Shams University, Cairo, Egypt.

ISSN $1110-6131$

Vol. 24(5): 161 - 181 (2020)

www.ejabf.journals.ekb.eg

\title{
Spatial and Temporal Distribution of Plankton in a Tropical Reservoir, southwestern Nigeria
}

\author{
Adedolapo A. Ayoade ${ }^{1 *}$ and Ashiat Aderogba ${ }^{2}$
}

1. Hydrobiology and Fisheries Unit, Department of Zoology, University of Ibadan, Ibadan, Oyo State, Nigeria

2. Ecology and Environmental Biology Unit, Department of Zoology, University of Ibadan, Ibadan, Oyo State, Nigeria

*Corresponding Author: : kenpeadobece@gmail.com

\begin{abstract}
ARTICLE INFO
Article History:

Received: May 5, 2020

Accepted: June 28, 2020

Online: July, 2020

Keywords:

Awba reservoir, Blue-green algae,

Zooplankton,

Temporal variation,

Nigeria

ABSTRACT

Spatial and temporal variations in the distribution of plankton of a tropical reservoir were investigated for six months. Chlorophyceae was richest in the phytoplankton community in term of the number of species and individuals. They were more abundant in the late rainy /early dry season with Pediastrum simplex and Coelastrum chodati being the dominant species. Constant species occurred only in Chlorophyceae, which included Spirogyra, Closterium sp., Coelastrum chodati, Pediastrum simplex, Ulothrix zonata and Scenedesmus quadricauda. Cyanophyceae developed mainly in the late dry season months (reached peak in March) with Microcystis flos-aqua being dominant. In the zooplankton community, Crustacea had the highest number of individuals and were more abundant in the late dry season. Camptocercus sp., Bosmina sp. and Daphnia magna were the main species. Rotifers had the highest species number with peaks observed in the late rainy/early dry season. The common species encountered included Chromagaster sp., Epiphanes sp., Gastropus sp., Nolthoca sp., Trichocerca sp., and Brachionus sp. The common protozoan species were Ichthyophthrius, Chilodonella, Prorodon and Colpoda. The diversity indices calculated varied spatially; phytoplanktonic organisms were more diverse in Station 1 with the least evenness, highest evenness occurred in Station 2. The increase in total number of taxa encountered in this study compared to previous studies and implication of Microcystis flos-aqua being the dominant blue-green algae were discussed.
\end{abstract}

\section{INTRODUCTION}

The quality and quantity of water in reservoirs are very important especially in reservoirs with multifunctional roles. The health of the aquatic ecosystem of lakes are very sensitive issues and lakes in different regions of the world particularly in developing countries are facing a variety of problems associated with anthropogenic activities and unsustainable use of their resources as demonstrated by El-Serehy et al. (2018). Deterioration of water quality in reservoirs results from excessive nutrients inputs, eutrophication, acidification, heavy metal contaminants, organic pollutants and obnoxious fishing practices as asserted 
by Gupta (2014). The monitoring of water quality of reservoirs is important as it helps with the management of the eutrophication and productivity of the water body. Eutrophication has a considerable impact on the two main components of the plankton communities (phytoplankton and zooplankton) causing many changes in their abundance and species composition and affecting the relationships between them. Changes in the plankton community structure in relation to physicochemical parameters may be a first sign of deterioration in the water quality (Ochocka and Pasztaleniec, 2016). They also suggested that both plankton elements (phytoplankton and zooplankton) should be taken into account in the ecological status assessment of lakes. Studies on the structure and functioning of planktonic communities in reservoir ecosystems provide opportunities to investigate patterns of responses to cyclical variations and episodic disturbances as suggested by Nogueira (2001) Biomass, taxonomical composition and diversity of phytoplankton are part of the criteria on which the trophy of a water body might be assessed as suggested by OECD (1982). The habitat-template approach proposes that algal attributes are matched to opportunities provided by the environment and that there is an encouraging fit of phytoplankton species to the range of habitats described by the trophic spectrum as written by Akin-Oriola (2003). The changes in the phytoplankton community can be particularly useful as an assessment tool, due to their rapid response to environmental stress. The qualitative and quantitative studies of phytoplankton may provide good indices of water quality and capacity of water to sustain heterotrophic communities as suggested by Agarwal et al. (2018)

Zooplankton is one of the most important biotic elements that impact all functional aspects of aqueous ecosystems including food chains and trophic networks, energy flow, and the circulation of matter as asserted by Paturej et al. (2017). Species composition and abundance of zooplankton communities can be influenced by a number of physical, chemical and biological factors as demonstrated by Sampaio et al. (2002). The composition and abundance of zooplankton have been reported to be significantly impacted by the trophic state of reservoirs (Pinto-coelho et al., 2005; Paturej, 2006; Kudari and Kanadami, 2008 and Gonzalez et al., 2011)

Awba Reservoir, a man-made lake on the Awba Stream, University of Ibadan serves as a source of water supply to the water treatment plant for domestic uses in the University. The Awba stream however receives untreated effluents from the staff and student residences, Zoological Garden, Faculty of Science laboratories and its environment. Recently, the lake has been earmarked for ecotourism alongside water supply; waterbased tourism activities include boating, sailing, motor boating, swimming, skiing, and fishing activities, these are often less detrimental to water quantity and quality compared to many other human uses of water like agriculture, industry etc. as suggested by Long (2012). Previous studies on the ecology of the reservoir were recorded, including Mombeshora et al. (1981) on the trace metal level; Ugwumba and Adebisi (1992), on food and feeding relationship in fish; Akin-Oriola (2003), Chukwuka and Uka (2007); Anago et al. (2013) on plankton composition and Aderogba \& Ayoade (in press) on trophic status. The aim of this paper was to update knowledge on the current status of limnology of the reservoir through assessment of the plankton composition and abundance of the Awba reservoir, Ibadan. 


\section{MATERIALS AND METHODS}

The Awba reservoir on latitude $7^{\circ} 26^{\prime}-7^{\circ} 27^{\prime} \mathrm{N}$ and longitude $3^{\circ} 53^{\prime}-3^{\circ} 54^{\prime} \mathrm{E}$ (Figure 1) is located in the University of Ibadan, south western region of Nigeria about $160 \mathrm{~km}$ from the Atlantic Ocean coast at an altitude of $185 \mathrm{~m}$ above sea level as written in AkinOriola (2003). The reservoir was constructed in 1964 with a maximum depth of $5.5 \mathrm{~m}$ and surface area of about 6 ha. The annual rain occurs from April to October with a characteristic August break during which the rain abates. The water of the lake is still with occasional multi-directional water movements due to wind effects. Wind action in the reservoir is minimal in the dry season and the high temperatures at this period result in thermal stratification of the water. It is surrounded by a modified tropical rain forest vegetation with aquatic macrophytes such as Pistia stratiotes, Canna indica, Nymphae lotus, Banhima sp. on its edges as written in Akin-Oriola (2003).

Field sampling was conducted from October 2017 to March 2018 (October- January, late rainy/early dry season; February - March, late dry season) at monthly interval from three selected sampling stations on the reservoir. Plankton were collected with a $55 \mu \mathrm{m}$ bolting silk plankton net and preserved in $4 \%$ formalin. One $\mathrm{mL}$ of a sub-sample was randomly taken from the bottle by using pipette and placed into a Sedgewick Rafter counting cell and slowly covered with a cover slip. Sorting, identification, and counting were carried out under a compound microscope. Plankton identification was analysed at the lowest possible taxonomic level according to the standard taxonomic references (Whitford and Schumacher 1973; Needham and Needham 1974; Jeje and Fernardo 1987 and Nwankwo 2004).

Diversity was evaluated using the Shannon Wiener index (Pielou 1975). Margalef's Index (d) known as species richness index was calculated as given by Margalef (1958). Evenness (E) expresses the degree of uniformity in the distribution of individual among the taxa was also calculated as given by Magurran (1988). The Sørensen index by Sørensen (1948) was used to compare the plankton species compositions of the different stations. Species were classified according to their frequency of occurrence as: constant (50\% or more), common (between $10 \%$ and $50 \%$ ) or rare (below 10\%), as described in Gomes (1989).

\section{RESULTS}

\section{Phytoplankton Composition and Abundance}

The phytoplankton composition of Awba reservoir during the study period was represented by 7 families, 83 genera and 126 species. Chlorophyceae was the dominant form in the community in term of number of species (70) and abundance $\left(9.63 \times 10^{5}\right.$ organisms $/ \mathrm{mL}$ ). This was followed by Cyanophyceae with 28 species and $4.79 \times 10^{5}$ organisms/mL. Most abundant species were Pediastrum simplex (Meyen) Lemmermann (green algae, $1.78 \times 10^{5}$ organisms/mL), Coelastrum chodati Ducellier (green algae, 1.71 x $10^{5}$ organisms $/ \mathrm{mL}$ ), Closterium gracile Breb. (desmid, $1.49 \times 10^{5}$ organisms $/ \mathrm{mL}$ ) and Microcystis flos-aqua (Wittr.) Kirchner (blue green algae, 1.04 x $10^{5}$ organisms $/ \mathrm{mL}$ ) Table 1. The total number of species varied from 76 in Station 1 to 89 in Station 2. However, the highest phytoplankton abundance was recorded in Station 1(7.24 x 10 
organisms $/ \mathrm{mL}$ ) and the least in Station 3(4.24 x $10^{5}$ organisms $\left./ \mathrm{mL}\right)$. Generally there was a gradual decrease in abundance of major phytoplankton group from Station 1 to Station 3 except Chrysophyceae and Euglenophyceae (Figure 2).

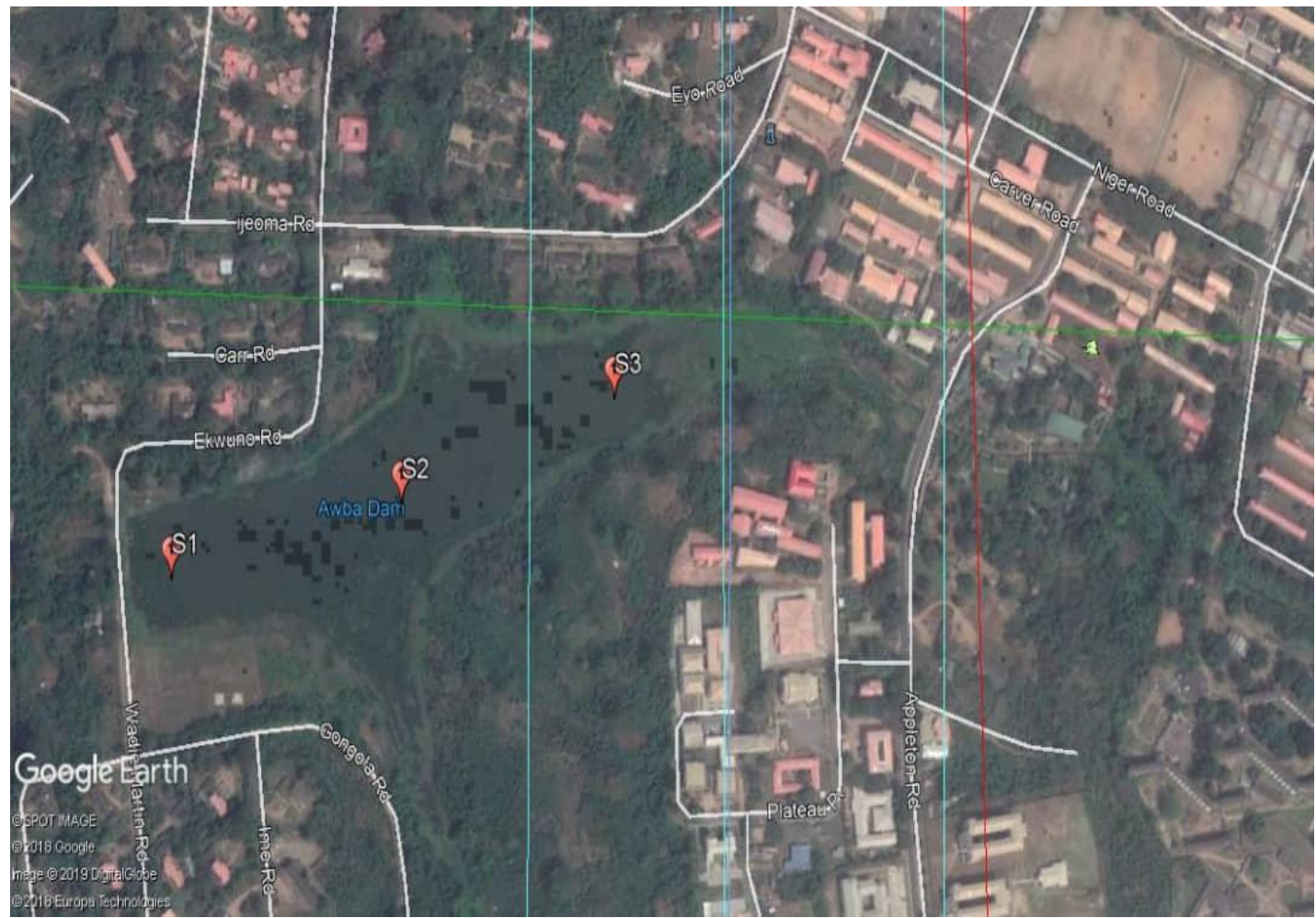

Legend: S1 - Station 1, S2- Station 2, S3- Station 3

Figure 1: A map of University of Ibadan Showing Awba Reservoir and Sampling Stations

Table 1: Relative abundance of phytoplankton organisms of Awba Reservoir, Ibadan, Nigeria

\begin{tabular}{|lll|}
\hline CHLOROPHYCEAE & $\begin{array}{l}\text { Total Abundance } \\
\text { (Organism/ mL) }\end{array}$ & $\%$ \\
Actinastrum hantschii & 4000 & 0.23 \\
Ankistrodesmus sp. & 5000 & 0.29 \\
Asterococcus limenticus & 8000 & 0.46 \\
Binuclearia tatrana & 1000 & 0.06 \\
Botryoccoccus sp. & 9000 & 0.52 \\
Chlamydomonas feneserata & 5000 & 0.29 \\
Chlorella vulgaris & 32000 & 1.83 \\
Cladophora sp. & 1000 & 0.06 \\
Clostidium retigerum & 30000 & 1.72 \\
Coelastrum angustae & 39000 & 2.23 \\
Coelastrum chodati & 171000 & 9.78 \\
Coelastrum morus & 28000 & 1.60 \\
Coelastrum probescideum & 1000 & 0.06 \\
Coleochaete orbicularis & 2000 & 0.114 \\
\hline
\end{tabular}




\begin{tabular}{|c|c|c|}
\hline Coleoclaete scutata & 1000 & 0.06 \\
\hline Crucigenia crucifera & 1000 & 0.06 \\
\hline Crucigenia quadrata & 1000 & 0.06 \\
\hline Dispora crucgenibides & 1000 & 0.06 \\
\hline Dysmorphococcus variabilis & 1000 & 0.06 \\
\hline Eudorina elegans & 2000 & 0.114 \\
\hline Geminella minor & 2000 & 0.114 \\
\hline Gloeocystis botryoides & 10000 & 0.57 \\
\hline Gonphosphaeria wichurae & 18000 & 1.03 \\
\hline Groenbladia neglecta & 1000 & 0.06 \\
\hline Hematoccoccus lacustris & 5000 & 0.29 \\
\hline Hormidium rivulare & 4000 & 0.23 \\
\hline Hormidium subtle & 2000 & 0.114 \\
\hline Hydrodictyon sp. & 1000 & 0.06 \\
\hline Menoidium gracile & 1000 & 0.06 \\
\hline Microspora amoena & 22000 & 1.26 \\
\hline Mougeotia sp. & 3000 & 0.17 \\
\hline Myrecia globosa & 1000 & 0.06 \\
\hline Oedogonium sp. & 7000 & 0.40 \\
\hline Ophiocytium sp. & 1000 & 0.06 \\
\hline Oocystis vulgaris & 1000 & 0.06 \\
\hline Palmellococcus minutus & 1000 & 0.06 \\
\hline Palmellococcus protothecoides & 4000 & 0.23 \\
\hline Palmodictyon varium & 6000 & 0.34 \\
\hline Pandorina morum & 2000 & 0.114 \\
\hline Pediastrum boryanum & 4000 & 0.23 \\
\hline Pediastrum duplex & 47000 & 2.69 \\
\hline Pediastrum simplex & 178000 & 10.18 \\
\hline Protoccocus sp. & 1000 & 0.06 \\
\hline Pseudendodonium sp. & 1000 & 0.06 \\
\hline Quadrigula closteriodes & 1000 & 0.06 \\
\hline Scenedesmus abundans & 7000 & 0.40 \\
\hline Scenedesmus acuminatus & 2000 & 0.114 \\
\hline Scenedesmus armatus & 27000 & 1.55 \\
\hline Scenedesmus bijuga & 1000 & 0.06 \\
\hline Scenedesmus oahuensis & 5000 & 0.29 \\
\hline Scenedesmus obliges & 2000 & 0.114 \\
\hline Scenedesmus opoiensis & 3000 & 0.17 \\
\hline Scenedesmus polifica & 7000 & 0.40 \\
\hline Scenedesmus quardricauda & 30000 & 1.72 \\
\hline Schroederia setigera & 1000 & 0.06 \\
\hline Schitochlamys gelatinosa & 1000 & 0.06 \\
\hline Sorastrum sp. & 1000 & 0.06 \\
\hline
\end{tabular}




\begin{tabular}{|c|c|c|}
\hline Spirogyra sp. & 34000 & 1.95 \\
\hline Spirotaenia sp. & 3000 & 0.17 \\
\hline Stigneoclonium carolinianum & 1000 & 0.06 \\
\hline Tetraspora sp. & 11000 & 0.63 \\
\hline Trebouria cladoniae & 8000 & 0.46 \\
\hline Ulothrix amphigranulata & 13000 & 0.47 \\
\hline Ulothrix terierrima & 1000 & 0.06 \\
\hline Ulothrix variabilis & 29000 & 1.66 \\
\hline Ulothrix zonata & 58000 & 3.32 \\
\hline Volvox dissipathrix & 3000 & 0.17 \\
\hline Volvox perglobator & 6000 & 0.34 \\
\hline Volvox proliticus & 16000 & 0.92 \\
\hline Zygnema sp. & 26000 & 1.49 \\
\hline Subtotal & 963000 & 55.09 \\
\hline \multicolumn{3}{|l|}{ DESMIDACEAE } \\
\hline Cosmarium cucumis & 32000 & 1.83 \\
\hline Closterium gracile & 149000 & 8.52 \\
\hline Gonatozygon aculeatum & 8000 & 0.46 \\
\hline Micraterias thomasiana & 2000 & 0.114 \\
\hline SUBTOTAL & 191000 & 10.93 \\
\hline \multicolumn{3}{|l|}{ CYANOPHYCEAE } \\
\hline Anabaena azolla & 13000 & 0.74 \\
\hline Aphanocapsa delicatissima & 36000 & 2.06 \\
\hline Aphanocapsa elachista & 3000 & 0.17 \\
\hline Aphanocapsa pulchra & 59000 & 3.38 \\
\hline Capsosira sp. & 1000 & 0.06 \\
\hline Chrococcus pactidus & 1000 & 0.06 \\
\hline Chrysococcus turgidus & 1000 & 0.06 \\
\hline Coelospharium kuetzingianum & 19000 & 1.09 \\
\hline Coelospharium naegeliarium & 8000 & 0.46 \\
\hline Cyanoptyche glococystis & 9000 & 0.52 \\
\hline Glosocapsa alpicola & 13000 & 0.74 \\
\hline Glosocapsa granosa & 4000 & 0.23 \\
\hline Glosocapsa lacustris & 1000 & 0.06 \\
\hline Glosocapsa magna & 1000 & 0.06 \\
\hline Lyngbya aerugineocarulea & 2000 & 0.114 \\
\hline Merismopedia convolute & 6000 & 0.34 \\
\hline Microcystis aeruginosa & 90000 & 5.15 \\
\hline Microcystis flos-aqua & 104000 & 5.95 \\
\hline Microcystis pulverea & 17000 & 0.97 \\
\hline Nostoc parmeloidies & 4000 & 0.23 \\
\hline Nostoc piscinade & 9000 & 0.52 \\
\hline Oscillatoria prolifica & 11000 & 0.63 \\
\hline
\end{tabular}




\begin{tabular}{|c|c|c|}
\hline Oscillatoria sancta & 51000 & 2.92 \\
\hline Phormidium angustisi & 2000 & 0.114 \\
\hline Phormidum corium & 7000 & 0.40 \\
\hline Phormidum teune & 3000 & 0.17 \\
\hline Rivularia sp. & 2000 & 0.114 \\
\hline Tolypothrix fragalis & 2000 & 0.114 \\
\hline SUBTOTAL & 479000 & 27.4 \\
\hline \multicolumn{3}{|l|}{ EUGLENOPHYCEAE } \\
\hline Euglena caudate & 26000 & 1.49 \\
\hline Euglena acus & 8000 & 0.46 \\
\hline Euglena deses & 12000 & 0.69 \\
\hline Euglena fusa & 6000 & 0.34 \\
\hline Euglena pronaina & 1000 & 0.06 \\
\hline Euglena spiroides & 3000 & 0.17 \\
\hline Eugelena varibilis & 1000 & 0.06 \\
\hline Trachelomonas ensifera & 3000 & 0.17 \\
\hline Trachelomonas horrida & 1000 & 0.06 \\
\hline Trachelomonas volgensis & 1000 & 0.06 \\
\hline SUBTOTAL & 62000 & 3.55 \\
\hline \multicolumn{3}{|l|}{ BACILLARIOPHYCEAE } \\
\hline Amphipleura pellucida & 2000 & 0.114 \\
\hline Cymbella sp. & 2000 & 0.114 \\
\hline Cyclotella sp. & 5000 & 0.29 \\
\hline Gyrosigma sp. & 1000 & 0.06 \\
\hline Mastigloia sp. & 6000 & 0.34 \\
\hline Navicula sp. & 7000 & 0.40 \\
\hline Nitzschia sp. & 7000 & 0.40 \\
\hline Rhizosolenia longiseta & 1000 & 0.06 \\
\hline Synedra sp. & 1000 & 0.06 \\
\hline SUBTOTAL & 32000 & 1.83 \\
\hline \multicolumn{3}{|l|}{ CHRYSOPHYCEAE } \\
\hline Amphichrysis compressa & 3000 & 0.17 \\
\hline Chrysamoeba radian & 3000 & 0.17 \\
\hline Chrysosphaera pacudosa & 1000 & 0.06 \\
\hline Uroglenopsis sp. & 1000 & 0.06 \\
\hline SUBTOTAL & 8000 & 0.42 \\
\hline \multicolumn{3}{|l|}{ XANTHOPHYCEAE } \\
\hline Tribonema sp. & 13000 & 0.74 \\
\hline SUBTOTAL & 13000 & 0.74 \\
\hline
\end{tabular}

Chlorophyceae dominated the phytoplankton community in late rainy /early dry season. Cyanophyceae were encountered mainly in the late dry season months and reached peak in March (3.59 x $10^{5}$ organisms/mL). Euglenophyceae also attained peak in abundance ( 7 species and $4.6 \times 10^{4}$ organisms/ $\mathrm{mL}$ ) in late dry season months Figure 3. Constant 
species according to criteria used occurred only in Chlorophyceae which included Spirogyra, Closterium sp, Coelastrum chodati Ducellier, Pediastrum simplex, Ulothrix zonata (Weber \& Mohr) Kutz. and Scenedesmus quadricauda (Turp.) Brebisson. The common blue-green algae included Coelosphaerium, Polycystis, Nostoc, Anabaena, Aphanocapsa, Microcystis flos-aqua, Phormidium corium (Ag.) Gom., Oscillatoria prolifica (Grev.) Gom., and Glosocapsa granosa (Berk.) Kutz. A large number of species were considered rare and represented by 35 green algae, 10 blue-green algae, 7 diatoms, 5 euglenoids, 3 golden algae and 1 yellow green algae.

\section{Zooplankton Composition and Abundance}

Three zooplankton taxa were identified and Crustacea made up the largest percentage (41.22\% of total zooplankton number) with Protozoa being the least (19.85\% of total zooplankton number), as in Table 2. However, rotifers (12) had the highest species number followed by protozoan (10). The species that were relatively more abundant were Camptocercus sp. (Cladocera, 12.98\%), Bosmina sp. (Cladocera, 12.21\%), Daphnia magna Straus, 1820 (Cladocera, 12.21\%), Chromagaster sp. (Rotifer, 11.45\%), Notholca sp. (Rotifer, 5.34\%), Ichthyophthrius sp. and Chilodonella sp. (Protozoa, $4.58 \%$ each) and Epiphanes sp. (Rotifer, 4.58\%). The highest zooplankton abundance occurred in Station 2(40\%) and least in Station 1(29.6\%) as in Figure 4. Rotifers dominated the zooplankton community in the late rainy/early dry season, while crustacean were more abundant in late dry season (Figure 5). The constant zooplankton according to criteria used was only microcrustaceans, Bosmina sp., and Camptocercus sp., while Daphnia, Coleps and Cypridopsis were common. Among the rotifers, the common species included Chromagaster, Epiphanes, Gastropus, Nolthoca, Trichocerca, and Brachionus. The common protozoan species were Ichthyophthrius, Chilodonella, Prorodon and Colpoda. The species considered to be rare were two crustaceans, three rotifers and six protozoans.

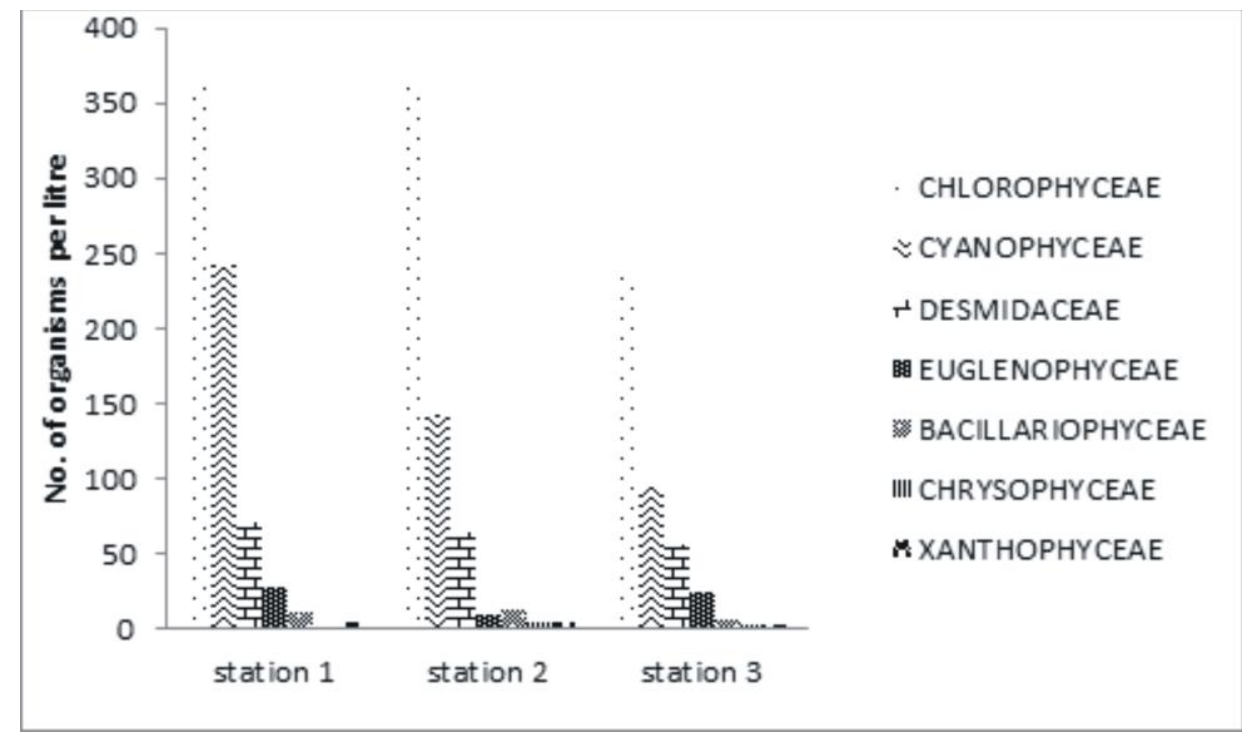

Figure 2: Spatial variation in abundance of major phytoplankton groups of Awba Reservoir 


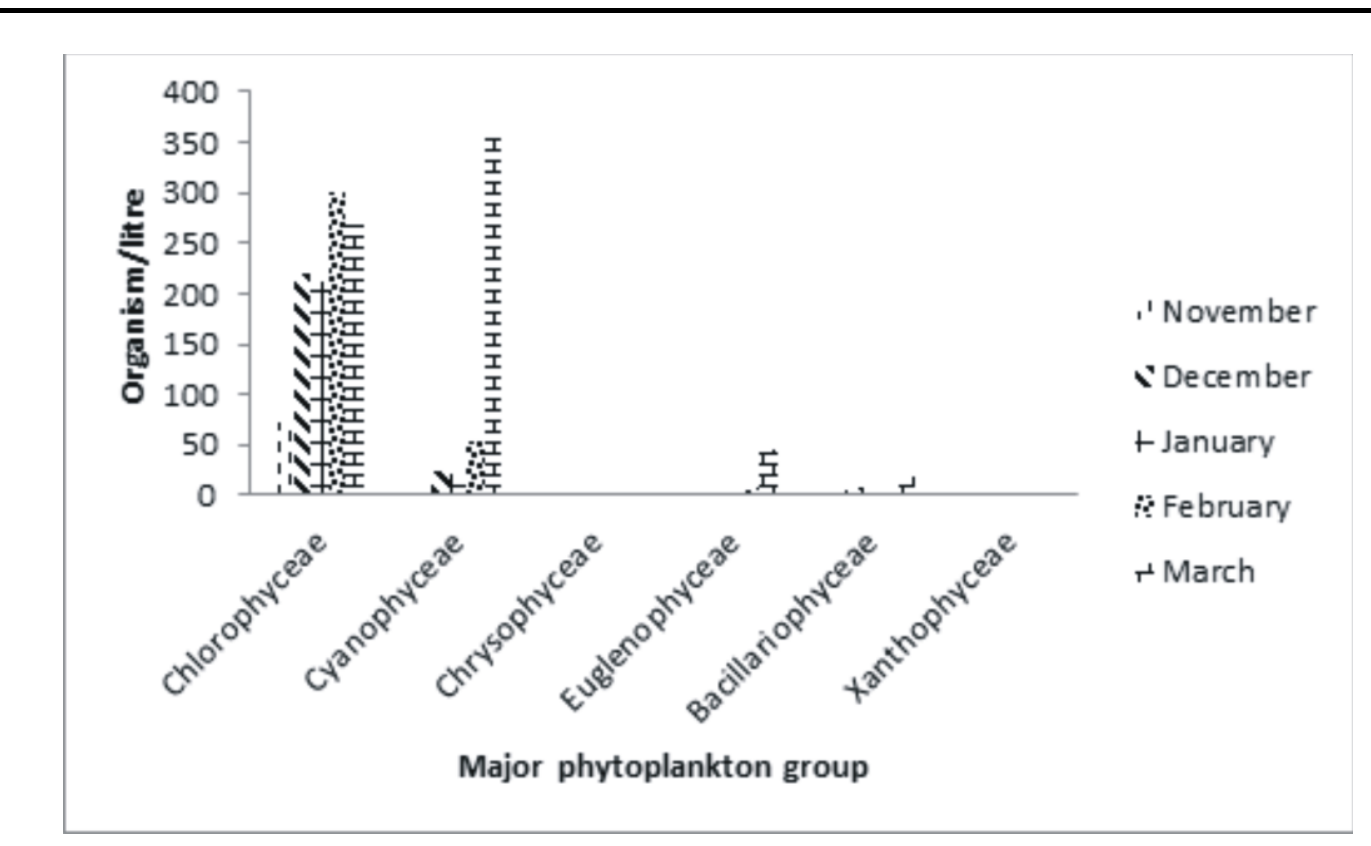

Figure 3: Temporal variation in abundance of major phytoplankton groups of Awba Reservoir

Table 2: Relative abundance of zooplankton organisms of Awba Reservoir, Ibadan, Nigeria

\begin{tabular}{|lll|}
\hline CRUSTACEA & Total Abundance & $\%$ \\
Bosmina sp. & Organism/ mL & 12.21 \\
Camptocercus sp. & 16000 & 12.98 \\
Daphnia magna & 17000 & 12.21 \\
Simocephalus sp. & 16000 & 0.76 \\
Cyclops sp. & 1000 & 0.76 \\
Cypridopsis sp. & 1000 & 2.29 \\
SUB TOTAL & 3000 & $\mathbf{4 1 . 2 2}$ \\
PROTOZOA & $\mathbf{5 4 0 0 0}$ & \\
Blepharisma sp. & 1000 & 076 \\
Chilodonella sp. & 6000 & 4.58 \\
Coleps sp. & 3000 & 2.29 \\
Colpoda sp. & 3000 & 2.29 \\
Frontonia sp. & 1000 & 0.76 \\
\hline
\end{tabular}




\begin{tabular}{|lll|}
\hline Ichthyophthrius sp. & 6000 & 4.58 \\
Lacrymaria sp. & 1000 & 0.76 \\
Prorodon sp. & 4000 & 3.05 \\
Spirostomum sp. & 1000 & 0.76 \\
Urostyla sp. & 1000 & 0.76 \\
SUB TOTAL & $\mathbf{2 6 0 0 0}$ & 19.85 \\
ROTIFERA & & \\
Brachionus urceolaris & 2000 & 1.53 \\
Chromagaster sp. & 15000 & 11.45 \\
Epiphanes sp. & 6000 & 4.58 \\
Euchlanis sp. & 3000 & 2.29 \\
Gastropus sp. & 5000 & 3.82 \\
Keratella sp. & 3000 & 2.29 \\
Notholca sp. & 7000 & 5.34 \\
Ploesoma sp. & 1000 & 0.76 \\
Rotaria sp. & 3000 & 2.29 \\
Syndiaeta sp. & 1000 & 0.76 \\
Testudinella sp. & 2000 & 1.53 \\
Trichocerca sp. & 3000 & 2.29 \\
suB TOTAL & 51000 & 38.93 \\
\hline
\end{tabular}




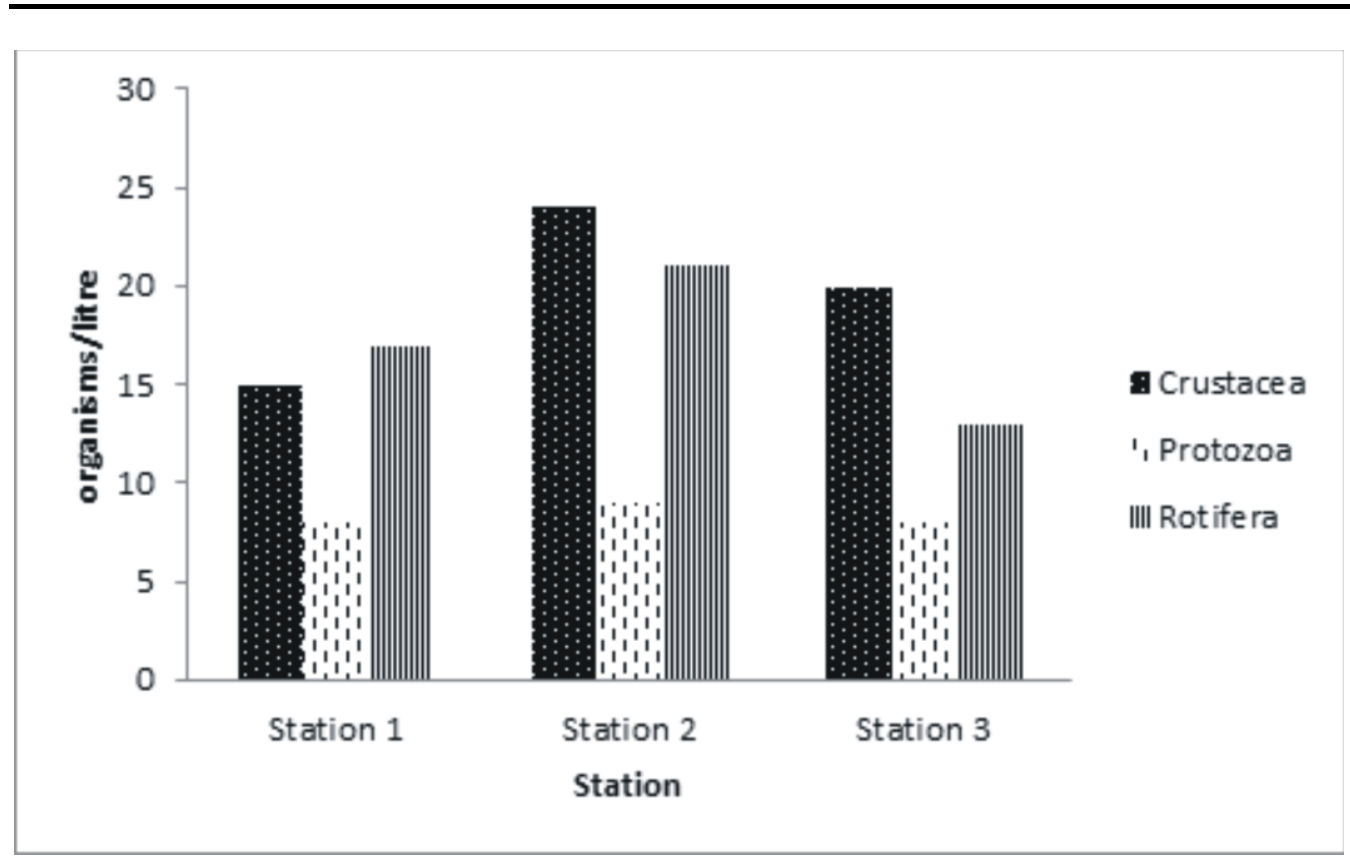

Figure 4: Spatial variation in abundance of major zooplankton groups of Awba Reservoir

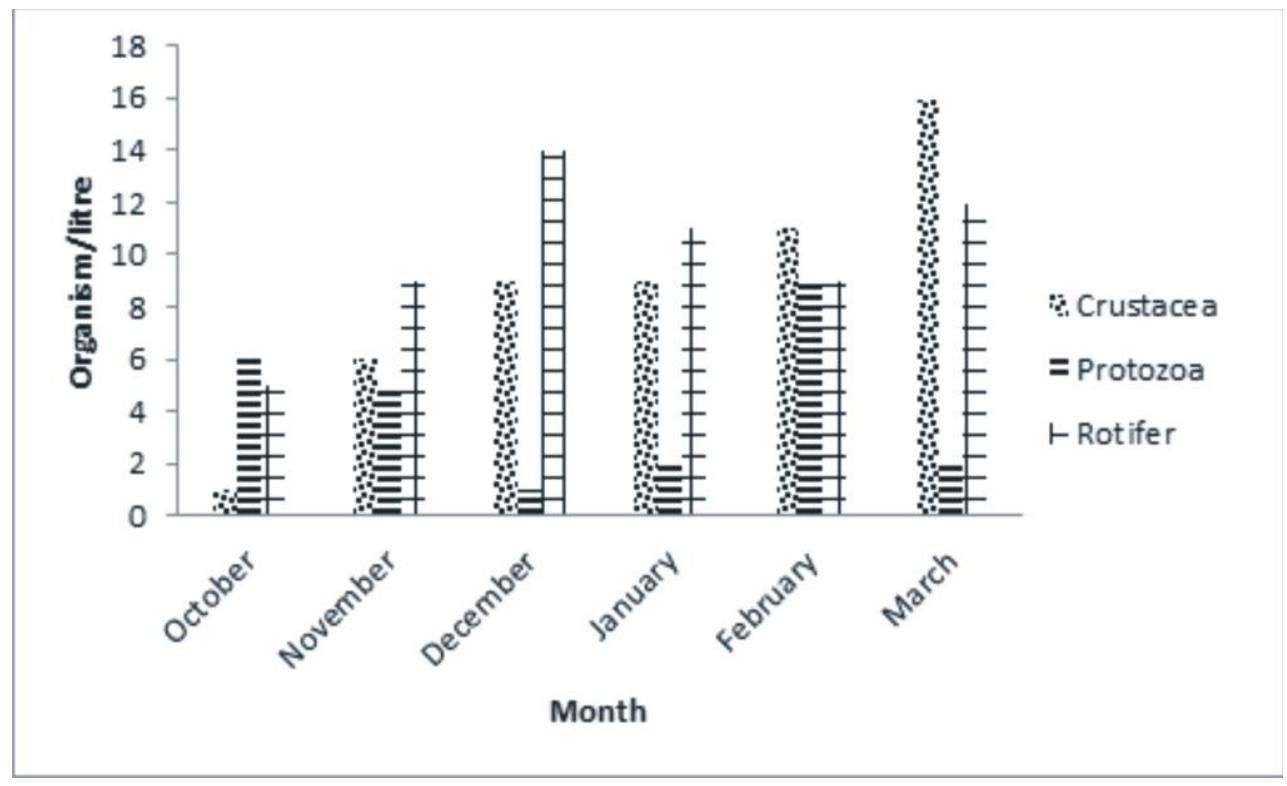

Figure 5: Monthly variation in abundance of major zooplankton groups of Awba Reservoir 


\section{Diversity Indices}

Monthly variation occurred in diversity indices of phytoplankton of Awba reservoir; Shannon- Wiener index H' ranged from 2.25 to 3.47 being lowest in the early dry season months. Lower values of Margalef's index D and evenness E were also obtained during early dry season months (Figure 6). The diversity indices calculated varied spatially; phytoplanktonic organisms were more diverse in Station 1 with the least evenness, highest evenness occurred in Station 2 (Figure 7). Zooplankton diversity indices obtained were lowest in Station 3; highest D occurred in Station 2 (Figure 8). Sorenson's coefficient of community similarity showed that phytoplankton $(0.64-0.68)$ and zooplankton (0.61-0.70) in the stations were alike/identical.

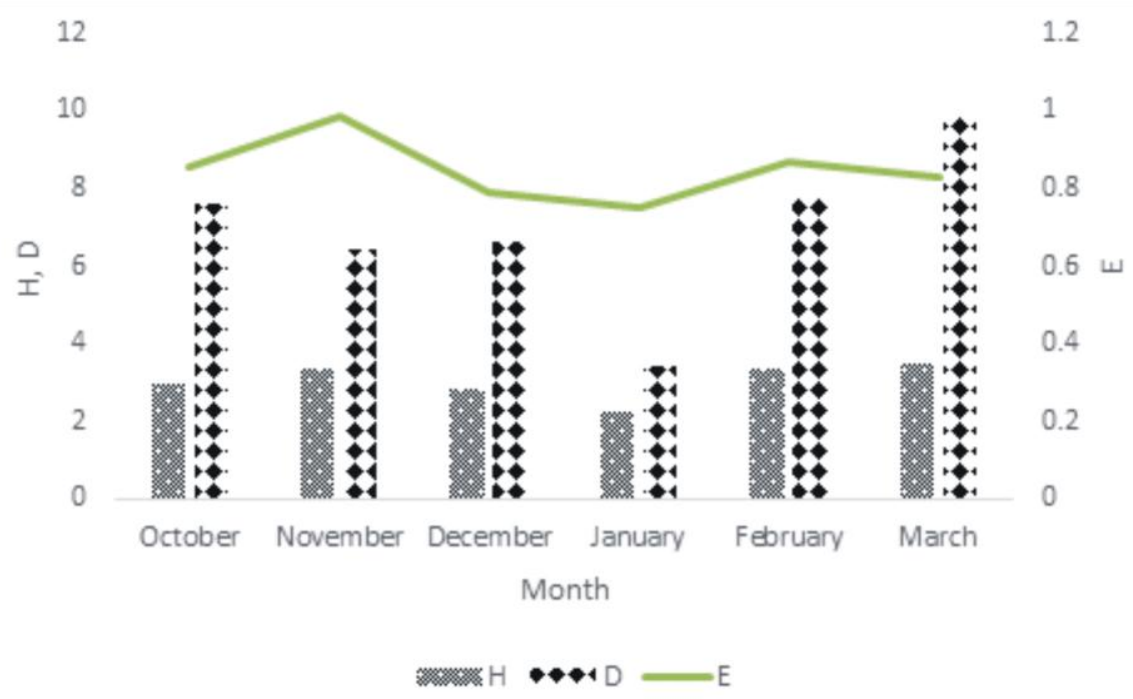

Figure 6: Monthly variation in phytoplankton diversity indices of Awba reservoir

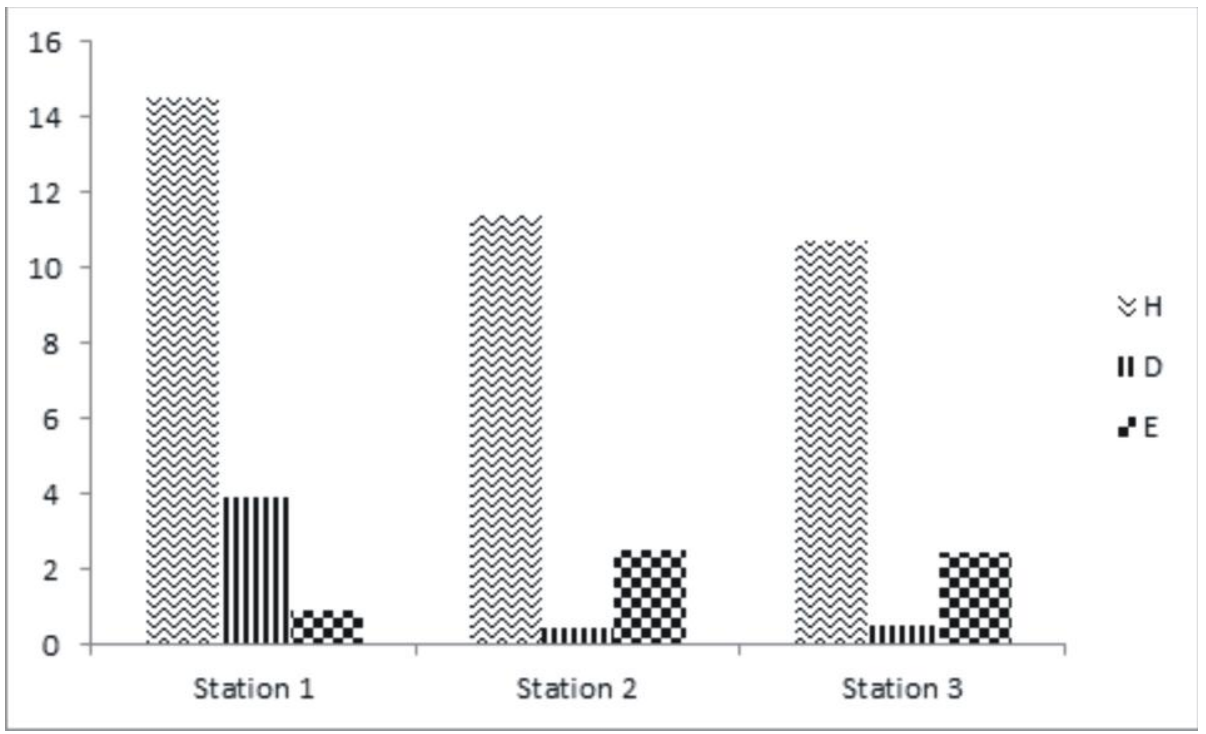

Figure 7: Spatial variation in phytoplankton diversity indices of Awba reservoir 


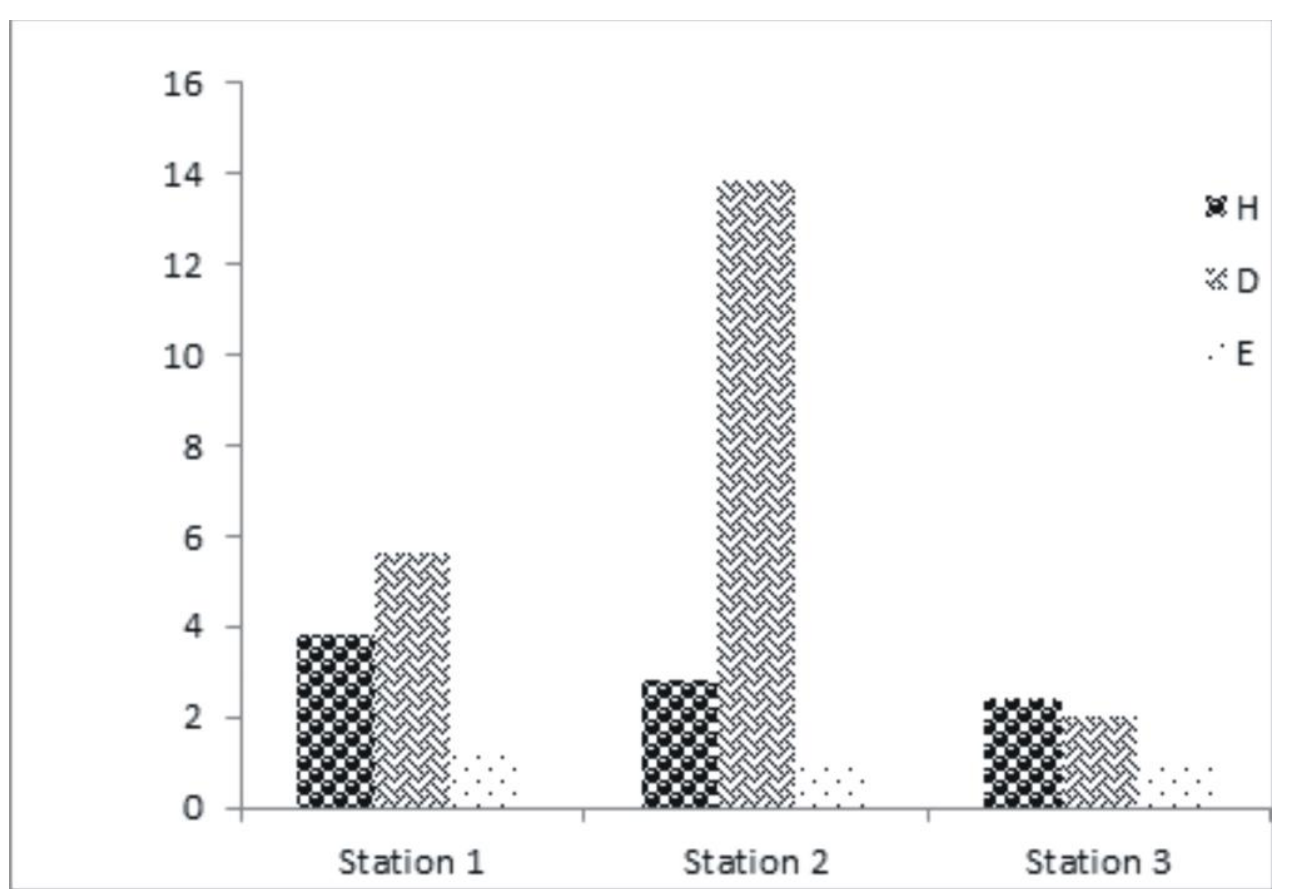

Figure 8: Spatial variation in zooplankton diversity indices of Awba reservoir

Table 3: WHO (1999) guidelines for algal bloom characterization

\begin{tabular}{|l|l|l|}
\hline Acute Health Effects & Cyanobacteria (cells/mL) & Microcystin-LR ${ }^{\star}(\boldsymbol{\mu g} / \mathbf{L})$ \\
\hline Low & $<20,000$ & $<10$ \\
\hline Moderate & 20,000 to 100,000 & 10 to 20 \\
\hline High & 100,000 to $10,000,000$ & 20 to 2,000 \\
\hline Very High & $>10,000,000$ & $>2,000$ \\
\hline
\end{tabular}

${ }^{a}$ Microcystin-LR is commonly used to represent microcystin congeners due to widely available data and known toxicity

Source: Wyoming Department of Environmental Quality Water Quality Division 2018

\section{DISCUSSION}

\section{Phytoplankton Composition and Abundance}

Non-motile green algae formed a major component of the phytoplankton community of the Awba reservoir with the larger green algae Pediastrum simplex and Coelastrum chodati being more abundant. According to Shubert (2003), the non-motile greens are ubiquitous and widely distributed in aquatic habitats throughout the North American continent. Chlorophyceae were also best represented in Lake Awasa, Lake Skadar and Thomas dam (Kebede and Belay 1994; Rakocevic-Nedovic and Hollert 2005; Ibrahim and Nafi'u 2017). This is contrary to the report of Akin-Oriola (2003) and Olagbemide (2011) that blue-green algae dominated the phytoplankton community of 
Awba reservoir, although the quantitative differences between the present study and the former may be due to expressing the abundance in organism $/ \mathrm{mL}$ thus cells in the colonial organism were not counted in this study. Generally there is an increase in total number of taxa encountered in this study compared to previous studies: 14 taxa, Akin-Oriola (2003); 43 taxa, Olagbemide (2011) and 49 taxa, Anago et al. (2013). This could be due to difference in methods of collection and sampling stations and also this suggests gradual eutrophication of the Awba reservoir according to Lepistö and Rosenström (1998), phytoplankton diversity in eutrophic waters is the highest compared to other types of trophic waters. Also several dominant species encountered in this study among the Chlorophyceae, Cyanophyceae (Aphanocapsa, Anabaena, Microcystis) and Euglenophyceae (Euglena acus Ehrenberg) are characteristic of eutrophic and mesotrophic lakes. The increase in the number of species according to the theory of intermediate disturbances Reynolds et al. (1993) was probably due to the slight changes in the ecosystem for example high nutrient concentration as reported by Aderogba and Ayoade (forthcoming).

Microcystis species, the predominant blue-green algae in the Awba reservoir are capable of rapid uptake of phosphate and nitrogen and hence producing large surface blooms and out competing other phytoplankton as asserted by Xie et al. (2003). Under conditions of nutrient enrichment or eutrophication, the blue-greens are known to proliferate and form noxious blooms in freshwater environments (Reynolds 1984, Stoyneva 2003). The bloom proportion reached by the Microcystis flos aqua and M. aeruginosa (Kūtz) in the reservoir during the late dry season is supported by the stratified nature of the reservoir (Ganf 1974; Akin-Oriola 2003). The formation of blooms also depends on retention time, type and age of water body as well as calm weather conditions with low turbulence of water (Bucka 1989). The development of phytoplankton blooms in eutrophic lakes is attributed to their ability to accommodate reduced nitrogen to phosphorus ratios, low edibility due to their large colony sizes coupled with large herbivore regulation of other taxa (Barica 1994, Paerl and Tucker 1995). Aderogba and Ayoade (forthcoming) reported low TN/TP ratio and advanced eutrophication of the reservoir.

M. aeruginosa blooms cause several environmental problems, including bad odor, bottom-layer hypoxia and the problem of greatest concern is the production of hepatotoxic cyanotoxins called microcystins by Harke et al. (2016). Cases of human poisoning as demonstrated by Jochimsen $\boldsymbol{e t}$ al. (1998), livestock intoxication (Beasley $\boldsymbol{e t}$ al. 1989), and mass mortality of wildlife (Miller et al. 2010) caused by microcystin contamination have been reported. Moreover, recent studies suggest increasing frequency of toxic (microcystin-producing) $M$. aeruginosa blooms in response to climate change as (Paerl and Otten 2013). The cyanobacteria densities (479,000 organism / mL) recorded in this study indicate high acute health effects/risk according to WHO (1999) guidelines for algal bloom characterization (Table 3). The Wyoming Department of Health (2018) identifies threshold values for microcystin $(\geq 10 \mu \mathrm{g} / \mathrm{L})$ and cyanobacteria density $(\geq$ 20,000 cells $/ \mathrm{mL}$ ), above which a recreational use advisory will be issued. Subsequently, Wyoming Department of Health will inform the water management agency, and notify local health authorities of the situation and provide information on common cyanobacteria and cyanotoxin related symptoms. Also, Wyoming Department of Environmental Quality (WDEQ) will notify public water supplies with intakes located on 
the surface water or downstream of surface water. The excessive abundance or blooming of eutrophic species has detrimental effects on the domestic, industrial and recreational uses of water and is in many cases a direct motivation for restorative measures (Bryant 1994). Thus, Awba reservoir may not be suitable for recreation/ecotourism in its present state.

The green algae being less abundant in the late dry season during the period of study could be due to thermal stratification of the water of Awba Lake in dry season (AkinOriola 2003), and once stratification is stabilized, the non-motile greens begin to sink and decline in the water column, and sedimentation increases. Non-motile greens appear to be restricted to a relatively short growth period defined by a narrow range of environmental conditions within which to successfully compete with a mixed assemblage of phytoplankton (Happey-Wood 1988). Thus seasonal succession was observed in the Awba reservoir and cyanophytes dominated in the late dry season.

The variation in the phytoplankton species richness and diversity with sampling points agreed with the findings of Sekandende $\boldsymbol{e t}$ al. (2004) in the satellite lakes of lake Victoria basin (Tanzania side) and Eyo et al. (2013) on the great Kwa River.

\section{Zooplankton Composition and Abundance}

The total number of species encountered in the zooplankton community of Awba reservoir in the present study differed in number and composition from the 13 species as given by Chukwuka and Uka 2007 and five species by Anago et al. (2013). Species composition and abundance of zooplankton communities can be influenced by a number of physical, chemical and biological factors as demonstrated by Sampajo et al. ((2002) especially temperature, quality and availability of food, competition and predation. The dominance of cladocerans in the zooplankton community of Awba reservoir during period of study could result from selective feeding by the invertebrate predators including fish on small-sized zooplankton like rotifers. Predation by invertebrates has a greater impact upon microzooplankton than on macrozooplankton, frequently reducing the abundance of the former as asserted Zaret (1980). Predation by fish may affect zooplankton structure, in accordance with the fish feeding mode: selective feeders, by differential capture of organisms, tend to eliminate large species, which are replaced by less vulnerable small forms (Brooks and Dodson 1965); filter-feeding planktophage fishes do not actively select their preys and therefore more evasive species avoid predation whereas small forms are captured, thus diminishing zooplankton densities (Drenner et al. 1982). Cladocerans were also dominant in Nigeen lake and Keenjhar lake (Jan et al. 2015; Rao and Azmi 2019), and attributed to temperature enhancing rapid hatching of eggs, high nutrient conditions and food availability as suggested by Pandit (1989). However, Chukwuka and Uka (2007) reported rotifers as the dominant group and Anago et al. (2013) encountered the copepod Thermocyclops as the most abundant. Cladocerans have been claimed to be good indicators of trophic state in lentic ecosystems. In Europe, the size range of species has been used as an indicator of water quality. According to Gannon and Stemberger (1978), species of Bosmina are good indicators of lake trophic state. Species such as Bosmina longirostris (O. E. Mūller), having a great ability to utilize colonial cyanophyceae as food, exhibit a greater tolerance to their blooms as suggested by Fulton and Paerl (1987), so that they become abundant 
in such conditions and may be considered bioindicators of eutrophication (MatsumuraTundisi 1999). Thus, the predominance of Bosminia and Camptocercus sp. in the reservoir suggests they feed on the colonial cyanophyceae and chlorophyceae that were dominant in the phytoplankton community and this further confirmed the eutrophic state of the reservoir. Bosmina longirostris has been observed in eutrophic environments such as Barra Bonita Reservoir (Matsumura-Tundisi 1999) and Billings Reservoir complex (Sendacz \& Kubo 1999) both in Brazil, however, Güntzel (2000) observed that among the six reservoirs on Tietê River, Bosmina hagmanni Stingelin, 1904 was most abundant in the less eutrophic ones.

Temporal variation and succession in zooplankton species was observed in the reservoir. Cladocerans reached peak in late dry season months coincided with bloom of Microcystis aeruginosa and $M$. flos aqua that could serve as food source. According to Campbell and Haase (1981), quality and quantity of food can alter species composition as well as the abundance of the species, since particular organisms are highly selective about the size and the type of phytoplankton they eat.

The frequently encountered protozoan species (Chilodonella spp., Ichthyophthirius) in the Awba reservoir could cause fish diseases. Protozoans exhibit rapid and exponential reproductive strategies (e.g. Chilodonella spp. and versatile, resilient life stages e.g. Ichthyophthirius multifiliis Fouquet which have allowed parasitic protozoans to colonise aquatic environments globally). Among fish protozoans, Ichthyophthirius and Trichodina are two of the most predominant genera globally (Lom and Dyková 1992). Ichthyophthirius multifiliis is one of the most contagious ciliophoran parasites of fishes (Matthews 2005; Dickerson 2006). This parasite accounts for significant economic losses in aquaculture, the ornamental fish trade and epidemics in wild fish populations, resulting in mass mortalities (Matthews 2005). The ciliated protozoan Ichthyophthrius multifilis infects several species of freshwater fish worldwide (Dickerson and Findly 2014). It causes high mortality associated with ichthyophthiriasis ("white spot disease") in farmed fish, while low-level infections occur in wild fish.

The genus Chilodonella includes free-living ciliated protozoa as well as pathogenic species for freshwater species, with Chilodonella hexasticha (Kiernik, 1909) and Chilodonella piscicola (Zacharias, 1894) being the most important ones. These parasites cause outbreaks with high mortalities among farmed freshwater fishes with great economic losses as demonstrated by Li et al. (2018). Heavy infection resulted in emaciation and mass mortalities. Infection in the gills caused severe degeneration, necrosis and consequent degradation of the branchial epithelium and occlusion of the capillaries. Infection also induced massive proliferation of chloride and mucus cells and also caused hyperplasia of the lining filamental epithelium. Paperna and Van As (1983) reported pathological and histopathological changes induced by infection of Chilodonella hexasticha (Kiernik) in wild and cultured cichlid fishes from Israel and South Africa.

In conclusion, the phytoplankton and zooplankton community of the Awba reservoir have increased species composition and abundance during the study period compared to previous studies. The abundance/bloom of Microcystis flos aqua further confirmed the advanced eutrophication of the reservoir. 


\section{REFERENCES}

Aderogba, A. and Ayoade, A. A. (forthcoming). Assessment of the trophic state of Awba reservoir, Ibadan, south.west Nigeria.

Agarwal, N. K.; Singh, H.; Singh, A. and Singh, G. (2018): Bhilagana river regulation for Tehri hydro power project in central Himalaya: Impact on planktonic assmblages. Biojounal 13(1): $1-10$.

Akin-Oriola, G. A. (2003). On the phytoplankton of Awba reservoir, Ibadan, Nigeria. Revis. Biol. Trop., 51(1): 99-106.

Anago, I. J.; Esenowo, I. K. and Ugwumba, A. A. A. (2013). The Physico-chemistry and plankton diversity of Awba Reservoir University of Ibadan, Ibadan Nigeria. Res. J.

Environ. Earth Sci., 5(11): 638-644

Barica, J. (1994). How to keep green algae in eutrophic lakes. Biol., 49(4): 611-614.

Beasley, V. R.; Cook W. O.; Dahlem, A. M.; Hooser, S. B.; Lovell, R. A. and Valentine, W. M. (1989). Algae intoxication in livestock and waterfowl. Food and Anim. Pract., 5: 345-361. doi: 10.1016/S0749-0720(15)30980-4

Brooks, J. L and Dodson, S. I. (1965). Predation, body size, and composition of plankton. Sci., 150: 28-35.

Bucka, H. (1989). Ecology of selected planktonic algae causing water blooms. Acta Hydrobiol., 31(3/4): 207-258.

Bryant, D.A. (ed.) 1994. The molecular biology of cyanobacteria. Kluwer.

Campbell, J. M and Haase, B. L. (1981). Availability of suitable phytoplanktonic food for zooplankton in an ice covered lake. Hydrobiol.,79: 113-119.

Chukwuka, K. S and Uka, U. N. (2007). Effect of water hyacinth (Eichornia crassipes) infestation on zooplankton populations in Awba reservoir, Ibadan southwest Nigeria. J. Biol. Sci., 7(6): 865 - 869

Dickerson, H. W. (2006). Ichthyophthirius multifiliis and Cryptocaryon irritans (Phylum Ciliophora). In: "Fish diseases and disorders". Woo, P. T. K. (Ed.). UK: Biddles, King's Lyn, pp. 116-153.

Dickerson, H. W. and Findly, R. C. (2014). Immunity to Ichthyophthirius infections in fish: A synopsis. Develop. Comp. Immunol., 43: 290-299.

Drenner, R. W.; De Noyelles Jr., F. and Kettle, D. (1982). Selective impact of filterfeeding gizzard shad on zooplankton community structure. Limnol. Oceano., 27(5): $965-$ 968.

El-Serehy, H. M.; Abdallah, H. S.; Fahad, A. A.; Irshad, R. S.; Al-Farraj, A. and 
Almalki, E. S. (2018). Aquatic ecosystem health and trophic status classification of the Bitter Lakes along the main connecting link between the Red Sea and the Mediterranean. Saudi J. Biol. Sci., 25: 204-212

Eyo, V. O.; Ekpo, P. B.; Andem, A. B. and Okorafor, K. A. (2013). Ecology and diversity of phytoplankton in the Great Kwa River, Cross River State, Nigeria. Inter. J. Fish. Aqua. Stud., 1(2):1-7

Fulton, R. S. III and Paerl, H. W. (1987). Effects of colonial morphology on zooplankton utilization of algal resources during blue-green algal (Microcystis aeruginosa) blooms. Limnol. Oceano., 32(3): 634-644.

Ganf, G. G. (1974). Diurnal mixing and the vertical distribution of phytoplankton in a shallow equatorial lake (Lake George, Uganda). J. Ecol., 62: 611-629.

Gannon, J. E. and Stemberger, R. S. (1978). Zooplankton (especially crustaceans and rotifers) as indicators of water quality. Trans Amer. Microsco. Soc., 97(1): 16-35.

Gomes, A. S. (1989). Distribuição espacial dos moluscos bivalves na região da plataforma continental de Cabo Frio, Praia de Maçambaba, Estado do Rio de Janeiro, Brasil. Dissertação de Mestrado, Universidade Federal do Rio de Janeiro, 122p.

Gonzalez, E. J.; Matos, M. L.; Penaherrera, C. and Merayo, S. (2011). Zooplankton abundance, biomass and trophic state in some Venezuelean Reservoirs. In: "Biomass and Remote Sensing of Biomass”, Atazadeh, I. (Ed.), Intech, Rijeka, pp. 57 - 74.

Güntzel, A. (2000). Variações espaço-temporais da comunidade zooplanctônica nos reservatórios do médio e baixo rio Tietê/Paraná, SP. Tese de Doutorado, Universidade Federal de São Carlos, 445p.

Gupta, M. (2014). A new trophic state index for lagoons. J. Ecos., 2014 (Article ID 152473) : $1-8$.

Happey-Wood, C. M. (1988). Vertical-migration patterns of flagellates in a community of freshwater benthic algae. Hydrobiol., 161: 99 -123.

Harke, M. J.; Steffen, M. M.; Gobler, C. J.; Otten, T. G.; Wilhelm, S. W.; Wood, S. A. and Paerl H W. (2016). A review of the global ecology, genomics, and biogeography of the toxic cyanobacterium, Microcystis spp. Harmful Algae 54: 4 - 20

doi:10.1016/j.hal.2015.12.007

Ibrahim, S. and Nafi'u, S. A. (2017). Phytoplankton as Indicators of Water Quality in Thomas Dam, Dambatta, Kano State, Nigeria. Dutse J. Pure and Appl. Sci., 3 (1):119-133

Jan, A.; Ashok, K. P. and Shah J, A. (2015). Diversity and abundance of zooplankton in Nigeen Lake of Kashmir Himalaya. Egpytian Acad. J. Biol. Sci., 7(2): 39 - 50

Jeje, C. Y. and Fernando, C. A. (1987). A practical gude to the identication of Nigerian zooplankton, Kainji Lake Research Institute, Nigeria. Pp 142 
Jochimsen, E. M.; Carmichael, W. W.; An, J. S.; Cardo, D. M.; Cookson, S. T; Holmes, C. E. et al. (1998). Liver failure and death after exposure to microcystins at a hemodialysis center in Brazil. New England J. Med., 338: 873-878 doi:10.1056/NEJM199803263381304

Kebede, E. and Belay, A. (2004). Species composition and phytoplankton biomass in a tropical African lake (Lake Awasa, Ethiopia). Hydrobiol., 288:13-32.

Kudari , V. A. and Kanadami, R. D. (2008). Impact of changed trophic status on the zooplankton composition of six water bodies of Dharwad district, Kanartaka State (South India). Environ. Monitor. Assess., 144(1-3): 301-313

Lepistö. L. and Rosenström, U. (1998). The most typical phytoplankton taxa in four types of boreal lakes. Hydrobiol., 369(370): 89-97.

Li, .M, Wang, R.; Gomes, G. B.; Zou, H.; Li, W.; Wu, S., Wang, G. and Ponce-Gordo, F. (2018). Epidemiology and identification of two species of Chilodonella affecting farmed fishes in China. Vet. Parasitol., 264: 8 - 17

Lom, J. and Dyková, I. (1992). Protozoan Parasites of Fishes. Developments in Aquaculture and Fisheries Science, Vol. 26, Elsevier, ISBN 0-444-89434-9, Amsterdam, The Netherlands

Long, P. H. (2012). Tourism Impacts and Support for Tourism Development in Ha Long Bay, Vietnam; An Examination of Residents Perceptions. Asian Soc. Sci., 8(8): 28-29. Management Madrid Spain Publications

Magurran, A. E. (1988). Ecological diversity and its measurement. Cambridge University Press, Cambridge

Margalef, D. R. (1958). Information theory in ecology. Inter. J. Gen. Syst., 3: 36-71

Matsumura-Tundisi, T. (1999). Diversidade de zooplâncton em represas do Brasil,. In: Ecologia de reservatórios: estrutura, função e aspectos sociais. pp. 39-54

FUNDIBIO/FAPESP, Botucatu, 799p

Matthews, R. A. (2005). Ichthyophthirius multifiliis Fouquet and Ichthyophthiriosis in Freshwater Teleosts. Adv.Parasitol., 59: 159 - 241

Miller, M. A.; Kudela, R. M.; Mekebri, A.; Crane, D.; Oates, S. C.; Tinker, M. T; Staedler, M.; Miller, W. A.; Toy-Choutka, S., Dominik, C. et al. (2010). Evidence for a novel marine harmful algal bloom: cyanotoxin (microcystin) transfer from land to sea otters. PLoS ONE 5 (9): 1-11 doi: 10.1371/journal.pone.0012576

Mombeshora, C.; Ajayi, S. O. and Osibanjo, O. (1981). Pollution studies on Nigerian rivers: Toxic heavy metal status of surface waters in Ibadan city. Environ. Inter., 5(1): 49-53.

Needham J G and Needham P R. (1974). A Guide to the Study of Freshwater Biology. $5^{\text {th }}$ Edition., Holden-Day Inc., San Francisco, C.A; Press, Raleigh, 324pp. 
Nogueira, M. G. (2001). Zooplankton composition, dominance and abundance as indicators of environmental compartmentalization in Jurumirim Reservoir (Paranapanema River), São Paulo, Brazil. Hydrobiol., 455: 1-18

Nwankwo, D. I. (2004). Studies on the environmental preference of blue-green algae (cyanophyta) in Nigeria coastal Water. The Nigeria Environ. Soc. J., 5(1):1- 8.

Ochocka A and Pasztaleniec A. (2016). Sensitivity of plankton indices to lake trophic conditions. Environ. Monitor. Assess., 188: 622 - 638

OECD.(1982) : Eutrophication of Waters. Monitoring, Assessment and Control. - 154 pp. Paris: Organisation for Economic Co- Operation and Development 1982.

Olagbemide, P. T. (2011). Phytoplankton density in Awba dam at different depths. Inter. J. Biosci., 6(1): $45-49$

Paerl, H. W. and Otten, T. G. (2013). Blooms bite the hand that feeds them. Sci., 342, 433-434. doi: 10.1126/science. 1245276

Paerl, H. W. and Tucker, C. S. (1995). Ecology of blue-green algae in aquaculture ponds. J. World Aqua. Soc., 26(2): 109 -131.

Pandit, A. K. (1989). Plankton dynamics in freshwater wetlands of Kashmir. In: "Ecology of polluted waters and toxicology”, K.D. Mishra eds. Technoscience Publications, Jaipur, India, pp $22-68$

Paperna, I. and Van As, J. G. (1983). The pathology of Chilodonella hexasticha (Kiernik). Infections in cichlid fishes. J. Fish Biol., 23(4): 441-450

Paturej, E.; Gutkowska, A.; Koszalka, J. and Bowsyzs, M. (2017). Effect of physicochemical parameters on zooplankton in the brackish, coastal Vistula Lagoon. Oceanol., 59: 49 - 56

Paturej, E. (2006). Assessment of the trophic state of the coastal Lake Gardno based on community structure and zooplankton - related indices. Electronic J. Polish Agric. Univ. 9(2) \#17.

Pielou, E. C. (1975). Ecological diversity. John Wiley, New York.

Pinto-Coelho, R.; Pinel-Allolul, B.; Methot, G. and Havens, K. E. (2005). Crustacean zooplankton in lakes and reservoirs of temperate and tropical regions: variation with trophic status. Can. J. Fishe. Aquatic Sci., 62(2): 348 -361

Rakocevic-Nedovic, J. and Hollert, H. (2005). Phytoplankton community and chlorophyll - a as trophic state indices of Lake Skadar (Montenegro, Balkan). Environ. Sci. Pollu. Res., 12(3): 146- 152

Rao, S. and Azmi, M. A. (2019). Species composition and occurrence of cladocera in Keenjhar lake, Sindh, Pakistan. Inter. J. Biol. and Biotech., 16(2): 509 - 512 
Reynolds, C. S.; Padisak, J. and Sommer, U. (1993). Intermediate disturbances in the ecology of phytoplankton and the maintenance of species diversity: a synthesis.

Hydrobiol., 249(1-3): 183-188.

Reynolds, C. S. (1984). The ecology of freshwater phytoplankton, Cambridge.

Sandgren, C.D. (1991), Growth and Reproductive Strategies of Freshwater

Phytoplankton. Cambridge University. Press, Cambridge, pp. 175-226.

Sampaio, E. V.; Rocha, O.; Matsumura-Tundisi, T. and Tundisi, J. G. (2002).

Composition and abundance of zooplankton in the limnetic zone of seven reservoirs of the Paranapanema River, Brazil. Brazil. J. Biol., 62(3): 525-545

Sekadende, B. C.; Mbonde, A. S. E.; Shayo, S.and Lyimo, T. J. (2004). Phytoplankton species diversity and abundance in satellite lakes of Lake Victoria Basin (Tanzanian side). Tanz. J. Sci., 30(1):83-89

Sendacz, S. and Kubo, E. (1999). Zooplâncton de reservatórios do Alto Tietê. In:" Ecologia de reservatórios: estrutura, função e aspectos sociais", R. Henry (ed.). Botucatu, FUNDIBIO/FAPESP, pp. 509-530.

Shubert, E. (2003). Nonmotile coccoid and colonial green algae. In:" Freshwater Algae of North America: Ecology and Classification (Aquatic Ecology)", Sheath, R. G, Wehr, J. D. and Thorp, J. H.(ed.). Academic Press, 994 pp.

Sørensen, T. (1948). A method of establishing groups of equal amplitude in plant sociology based on similarity of species content and its application to analyses of vegetation on Danish commons. Kongelige Danske Videnskabernes Selskab, Biologiske Skrifter 5: 1-34.

Stoyneva, M. P. (2003). "Steady-State Phytoplankton Assemblage in Shallow Bulgarian Wetlands. Hydrobiol., 502 (1-3): 169-177.

Ugwumba, A. A. A. and Adebisi, A. A. (1992). The food and feeding ecology of Sarotherodon melanotheron (Ruppell) in a small freshwater reservoir in Ibadan, Nigeria. Arch. Hydrobiol., 124 (3): 367-382.

WDEQ/WDH (2018). Harmful algal bloom action plan for publicly accessible lakes and reservoirs of Wyoming. Wyoming Department of Environmental Quality, Water Quality Division, Cheyenne, Wyoming.

Whitford, L. A. and Schumacher, G. J. (1973). A manual of Freshwater Algae. Sparks

Xie, L.Q. Xie, P. and Tang, H. J. (2003). Environment of dissolved phosphate release from sediment to lake water by Microcystis biomass- An enclosure experiment in a hyper eutrophic Chinese lake. Environ. Pollu., 122: 391-399.

Zaret, T. M. (1980). Predation and freshwater communities. Yale University Press, New Haven, 187pp. 